\title{
The Relationship Between Population and Economic Development: Evidence from Little Country's (Ethiopia, Uganda, Pakistan and China)
}

\author{
Mr. Israel Bereket (MSc) \\ Department of Economics, College of Business and Economics, Jinka University, Jinka, Ethiopia
}

\begin{abstract}
The relationship between population growth and economic development has been a topic under debate for a long time. The relationship between population growth and economic development can be measured by looking at the impact of population growth on economic development and vice-versa. The relationship between population and economic development has recently spawned a large number of empirical studies, with remarkably mixed result. While many studies argue that population growth impedes economic development, others contend that the economic effects of population are rather simulative and some maintain that the two variables are not related at all. So this paper tried to put some comparison between the variable in terms of graph, by taking four country Ethiopia, Uganda, Pakistan and China as example; when I come to my conclusion the impact of population growth on economic development is different in the varying economies. When in developed countries, population growth helped to increase the Gross National Product, in developing countries the reverse is the case. So that I support the view that population is not the real problem, since there is proper policy that can create opportunity for the growing population, the high population to become relevant. However if the concerned body if fail to manipulate especially with regards to Less Developed Countries it become treat and challenge for the economic development of that country and the also high population cannot foster the economy when the largest portion is poor. Moreover it may bring different problem like continuously increasing dependency ratio, increase migration, unemployment, tends to lower man-land and man-resource proportions, can also increase the problems of inequalities in income distribution and generally it create poverty.
\end{abstract}

Keywords: Population Growth, and Economic Development

DOI: $10.7176 / \mathrm{DCS} / 10-7-01$

Publication date:July $31^{\text {st }} 2020$

\section{Introduction}

The relationship between population growth and economic development has been a topic under debate for a long time. Different economists have brought up their views as to the definitions of population growth, economic development, the relationship between them and how they impact or affect the varying economies (i.e. less developed economies, developed economies and transition economies). The relationship between population growth and economic development can be measured by looking at the impact of population growth on economic development and vice-versa. Economic development can be understood to mean the process by which the quality of life of the citizenry or population is improved. This can be attained by increasing the standards of living of the people. Population growth can be defined as a numerical increase in people who occupy a certain area measured within a period of time. Population increases when people are either born in a country or immigrate to a different country from their country of birth.

There are generally two strands of views about the impact of population growth on economic development: one view opposing population growth that population growth is a real problem while the other view is in favour of population growth. Both of the viewers put arguments for their views. The first view of population growth and development started from the Malthusian population trap (1798), Population increases geometrically (doubles, then. again doubles) But food production increases more slowly, The impact of population growth is deteriorating on So eventually, there is not enough food economic development by hampering economic growth and considers it is a real problem And something happens to reduce the population to match the food Supply e.g. Starvation, disease, war etc.

The followers of the first view argue based on population growth gives way to negative economic consequences and this should be a real concern for the developing country is a real problem while the other view is population is desirable not a problem. It is one of the basic factors of production. According to this view population growth is the real strength and power of a country. High population means high labour supply that leads to division of labour and economic growth. Both the stands of views present their arguments about population growth and economic development. Each of the views is supported

The relationship between population and economic development has recently spawned a large number of empirical studies, with remarkably mixed result. While many studies argue that population growth impedes economic development, others contend that the economic effects of population are rather simulative and some 
maintain that the two variables are not related at all.

Moreover, there are different research that tells about The negative impact of a fast growing population on economic development especially with regards to Less Developed Countries will come to bare when not properly managed.

\section{Economic Arguments for and against Population Growth:}

The question is that whether population growth is problem has created controversy among the economists since antiquity. The basic argument is concerned with assumption of that people are considered as both producers and consumer. At one extreme case, large and solid foundation of even cause of technological progress is the impelling force that has raised man from his primitive state and pushed him forward on the road of civilization (UN, 1973; Todaro, 1994:180). An equally considerable body of theory and speculation, however, asserts that the multiplication of mankind has had the contrary effects of forcing whole nations down into poverty and misery, generating crime and vice of descriptions and letting looses the scourges of war, and disease. Thus it is understood that population growth should be considered as additional manpower and productive capacity in one time while it should be regarded as an increase in the number of mouths to feed more for another time, or simultaneously by different scholars. This acknowledges that population growth is fashionable issue for economic development of a nation. For some scholars, population growth is a serious problem, but for others, it is not as much serious problem for economic development rather favourable for it. This controversy creates three different views, which are called Pessimistic, Optimistic and Neutralistic arguments.

\subsection{CASE STUDY: Pakistan, Uganda, Ethiopia and China.}

\section{Pakistan:}

According to Sher Ali, Amjad Ali and Amjad Amin (2014) the prime objective of this paper is to empirically tests the impact of Population growth on Economic Development of Pakistan for period of 1975-2012.

ARDL co-integration technique was incorporated to investigate the population and economic development relationship. He used the following model, $\mathrm{Y}=\beta 0+\beta 1 \mathrm{PG}+\beta 2 \mathrm{UN}+\beta 3 \mathrm{HRD}+\beta 4 \mathrm{TOP}+\mu(\mathrm{F}), \mathrm{Y}=\mathrm{GDP}$ Growth, $\mathrm{POP}=$ Population growth, $\mathrm{UN}=$ unemployment rate, HRD $=$ Human Resource Development, $\mathrm{TOP}=$ trade openness, $\mu=$ White noise error term.

The result of the model shows that the impact of population is positive and significantly contributed to economic development and also that population growth is not a real problem it may help the economic growth with large scale of labour force available and division of labour. But the problem associated with government and policy makers due to not effective policy that creates a problem of unemployment and leads to lacking of educational and health facilities. The government is advised to utilize this additional workforce efficiently as a policy tool to achieve high and desired level of growth. So the government of Pakistan should take in to account the problem and unemployment and development policy HRD when the country got tremendous growth, reduced unemployment and developed human capital (through HRD) the population growth will be corrected of itself.

\section{Population and GDP growth rate relationship:}

If we see the data from 1980-2015,

$>$ The average population growth rate is: -2.500108 .

$>$ The average GDP growth rate is: -4.69285 .

* graphical illustrations and computation,

GROWTH RATE OF GDP AND POPULATION OF PAKISTAN:

Figure 1.1: growth rate of GDP

\section{grgdp}

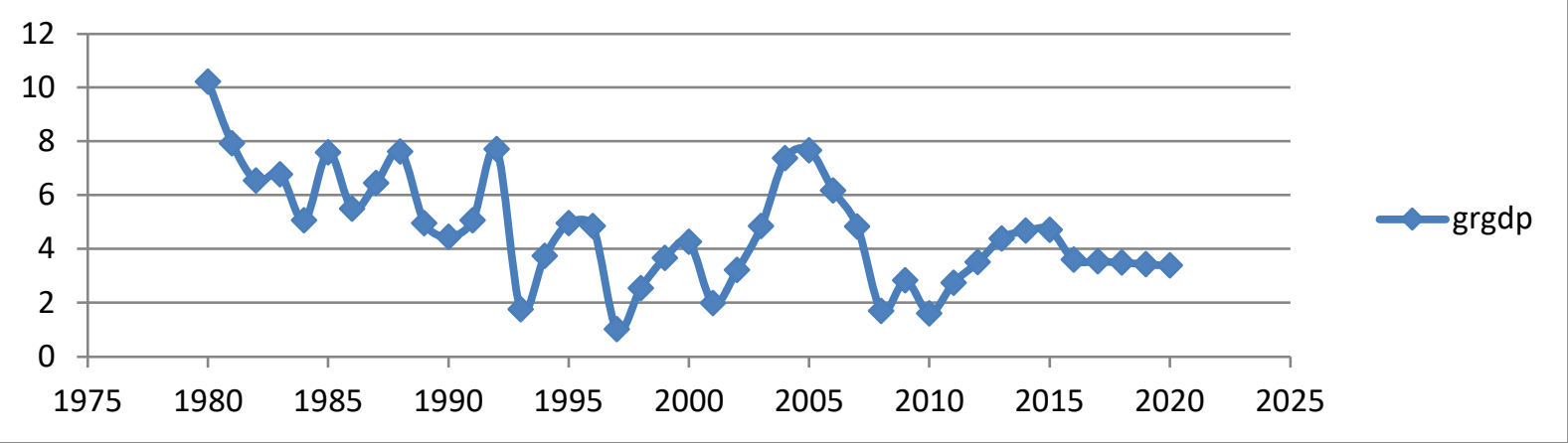

Source: own computation based on WB data. 
Figure 1.2 growth rate of population

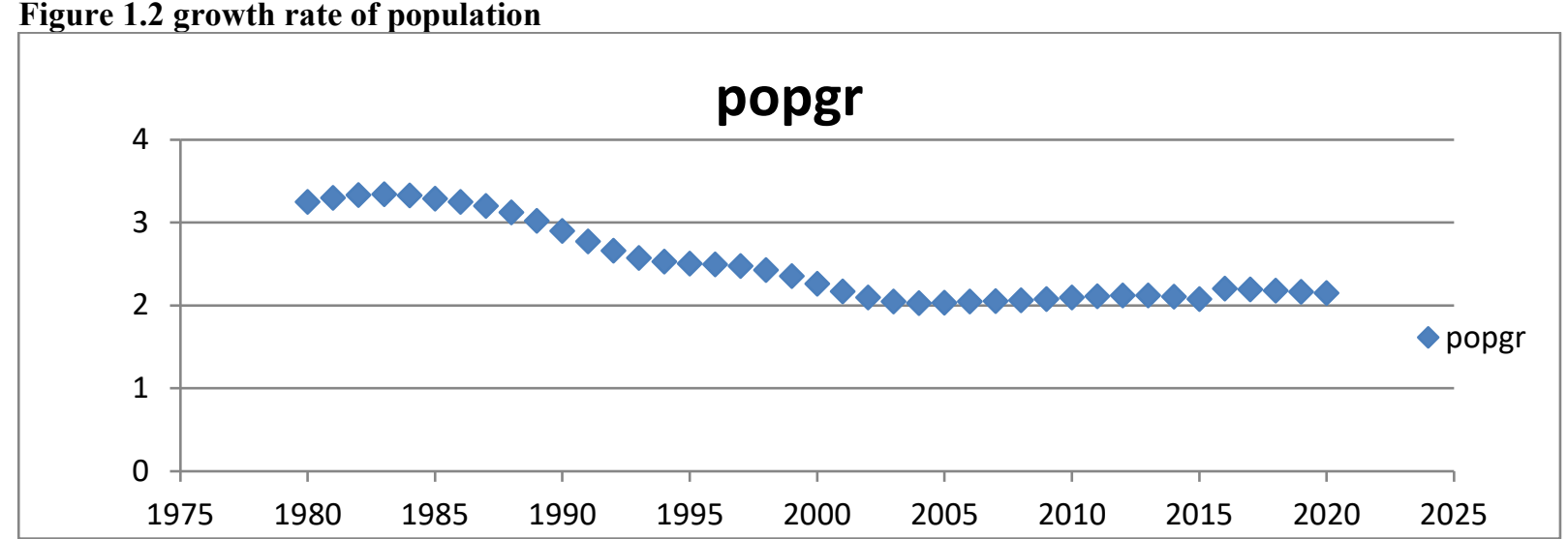

Source: own computation based on WB data.

Figure 1.3 growth rates of both GDP and population

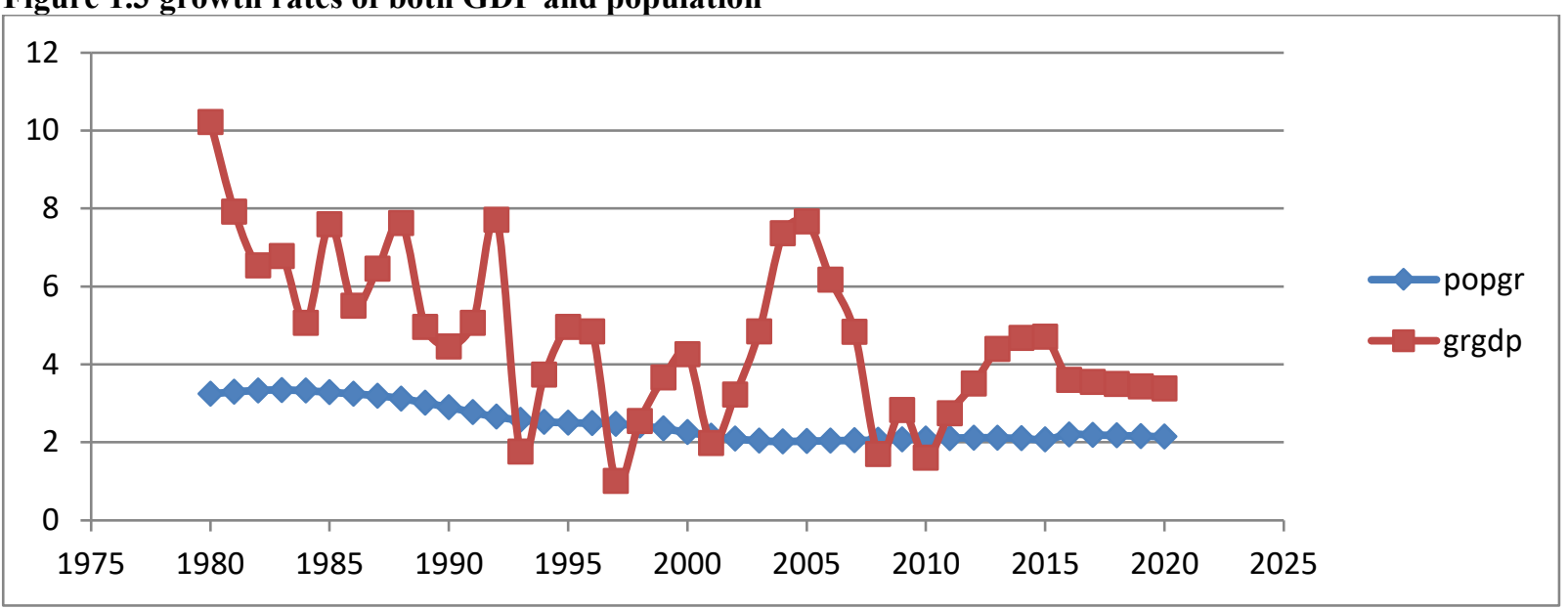

Source: own computation based on WB data.

Uganda:

According to Stephan Klasen and David Lawson (2009) the paper examines the Impact of Population Growth on Economic Growth and Poverty Reduction using the interesting case study of Uganda for time period 19602000. Although Uganda has recently experienced excellent economic growth and poverty reduction, it currently has one of the highest population growth rates in the world which, due to the inherent demographic momentum, will persist for some time to come.

By combining a Harrod-Domar Model and Solow Model with human capital, using both cross-sectional and panel data, they are able to consider the impact of population growth on per capita economic growth and poverty.

They found both theoretical considerations and strong empirical evidence suggest that the currently high population growth puts a considerable break on per capita growth prospects in Uganda. Moreover, it contributes significantly to low achievement in poverty reduction and is associated with households being persistently poor and moving into poverty. This is therefore likely to make substantial improvements in poverty reduction, and per capita growth, very difficult. so that The government must be manipulate economic incentives and disincentives to having children by either imposing financial penalties for having more than a certain number of children, subsidization of smaller families through direct money payments, reducing income tax relief when the number of children is kept within the limits stated and other mechanism that are important in order to reduce the negative impact on economic development.

Population and GDP growth rate relationship:

If we see the data from 1980-2015,

$>$ The average population growth rate is: -3.246476

$>$ The average GDP growth rate is: - 5.93757

- graphical illustrations and computation, 


\section{GROWTH RATE OF GDP AND POPULATION OF UGANDA:}

Figure 1.4: growth rate of GDP

\section{grgdp}

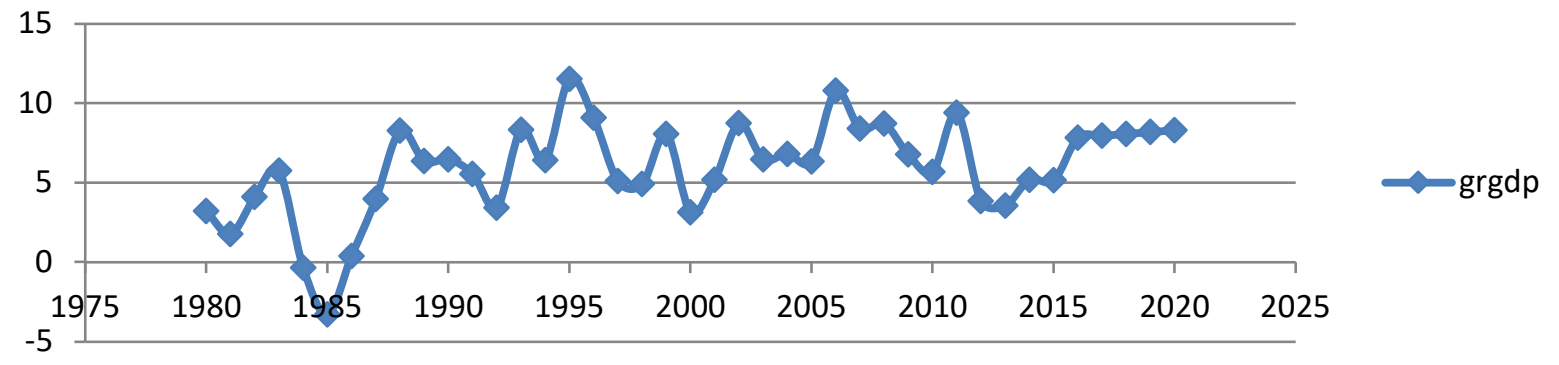

Source: own computation based on WB data.

Figure 1.5 growth rate of population

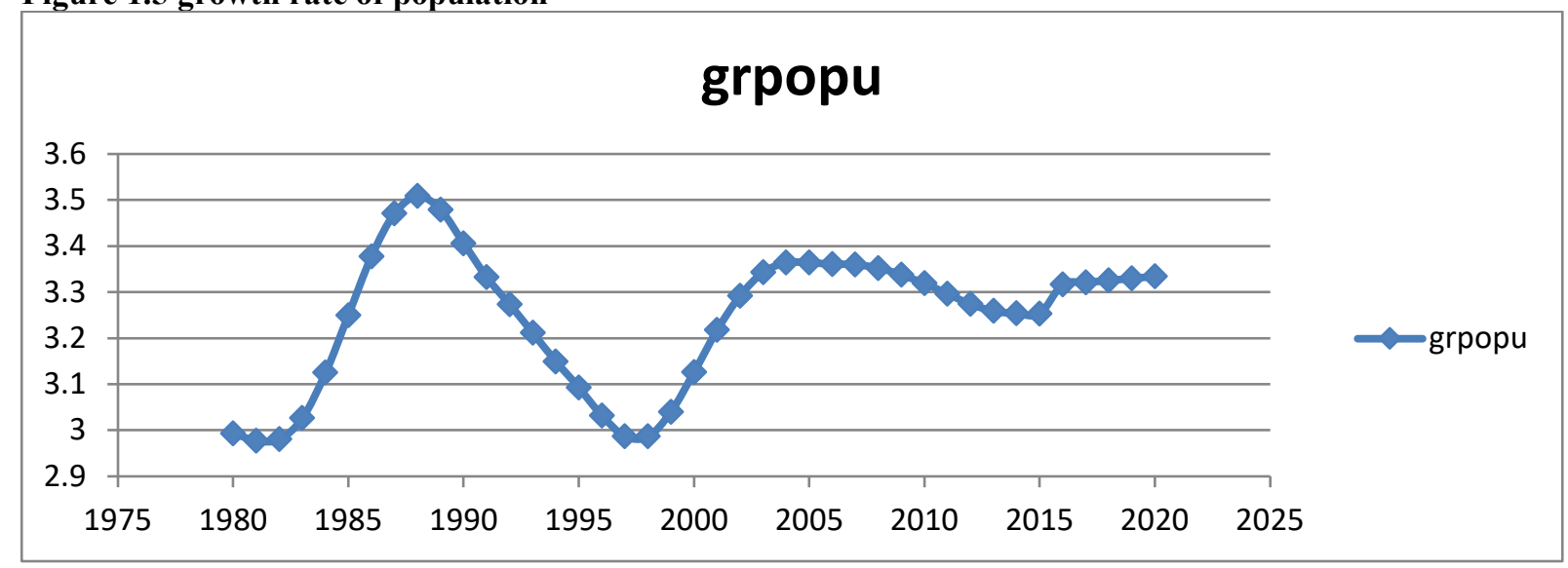

Source: own computation based on WB data.

Figure 1.6 growth rates of both GDP and population.

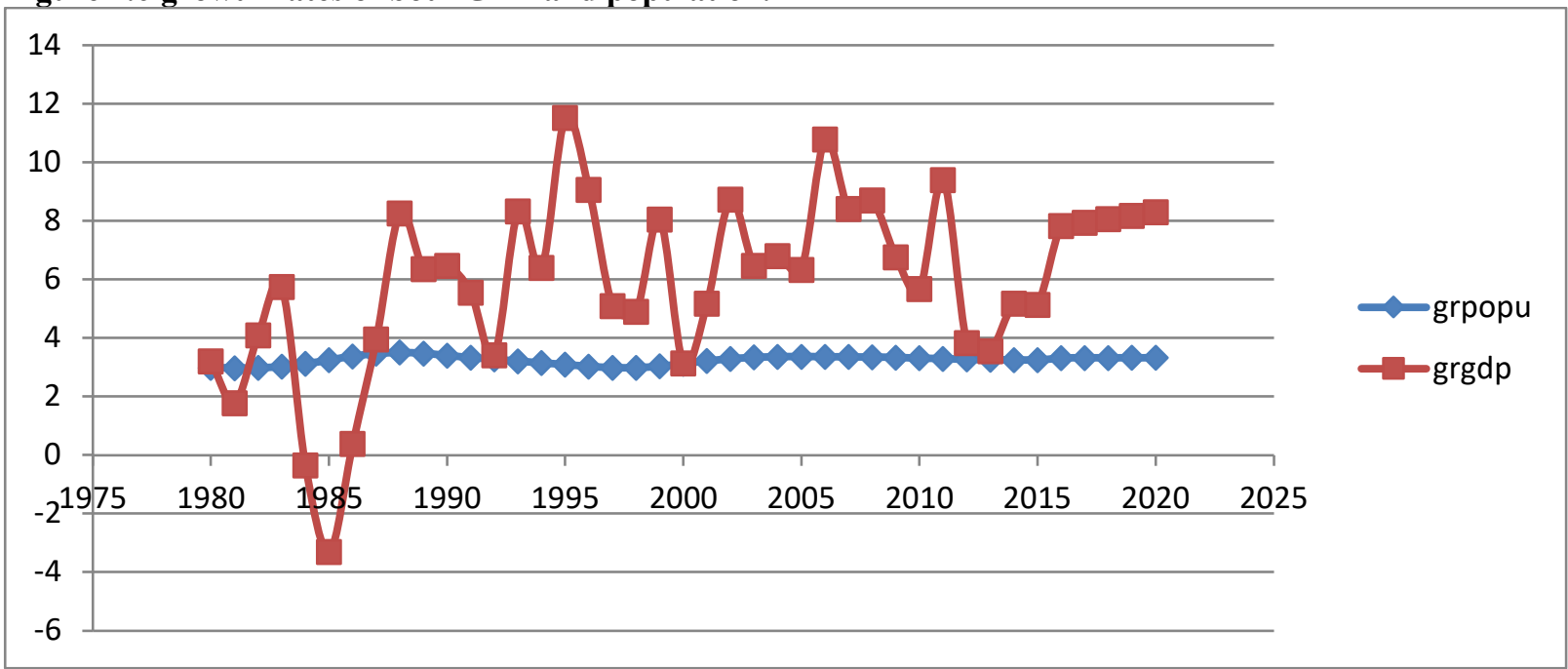

Source: own computation based on WB data.

Ethiopia:

According to Kassahun Alemu (2014) the prime objective of this paper is to empirically test the Impact of Population Growth on the Ethiopian Economic Performance. In fact Ethiopia is the second populous country in Africa while it is one of the Sub-Saharan Countries Trapped by poverty. Her population is increasing at an average rate of $2.5 \%$. 
He used the standard neoclassical model of economic growth and Econometric analysis has shown that population growth has had a significant negative impact in the short run but that of positive impact in the long run on the economic performance of the country. Thus realistic population policies should be designed and implemented to adjust/control high rate of population growth and make it a beneficial resource for the economy. For instance minimizing high birth rate can be an effective policy instrument since high birth rate can be a burden on the economy.

According to Martin (2011) also population growth contribute negatively for Ethiopian economy since A high rate of population growth not only has an adverse impact on improvement in food supplies, but also intensifies the constraints on development of savings, foreign exchange, and human resources. Also, too dense a population aggravates the problem of improving the health of the population and intensifies pressure on employment and the amount of investment available per labour market entrant.

Population and GDP growth rate relationship:

If we see the data from 1980-2015,

$>$ The average population growth rate is: -2.59696

$>$ The average GDP growth rate is: - 6.095065

* graphical illustrations and computation,

Figure 1.7: growth rate of GDP

GROWTH RATE OF GDP AND POPULATION OF ETHIOPIA:

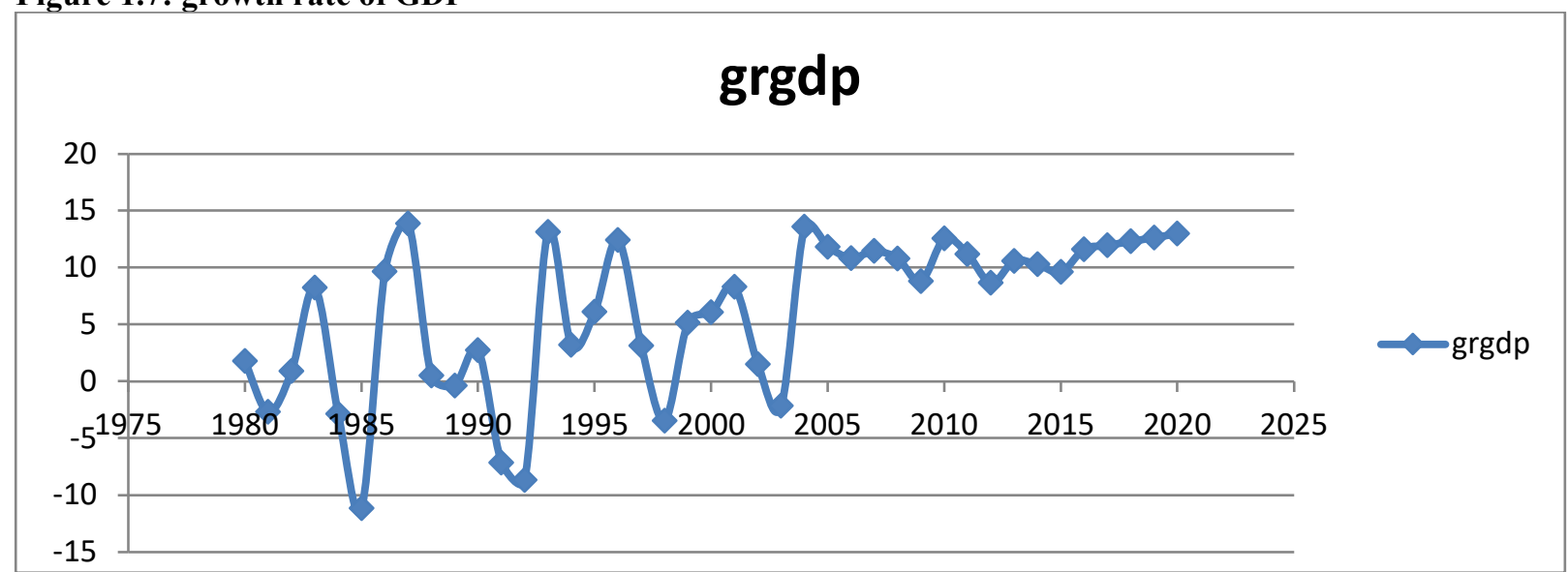

Source: own computation based on WB data.

Figure 1.8 growth rate of population

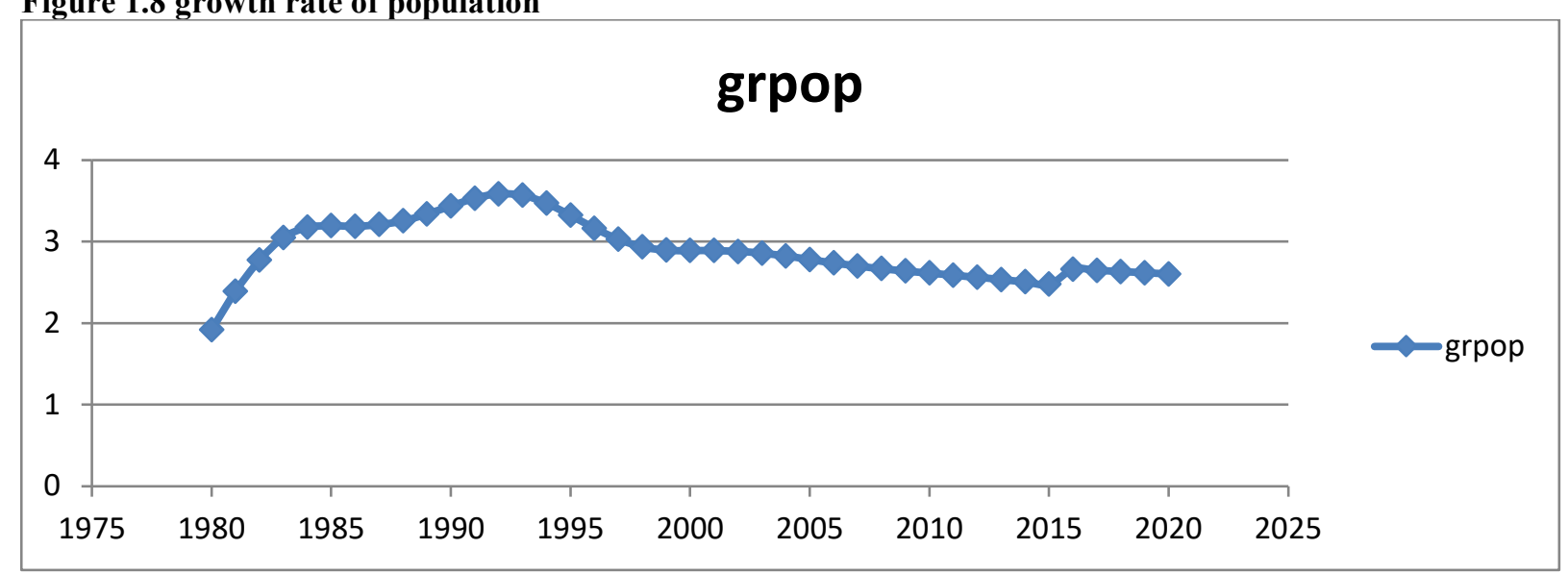

Source: own computation based on WB data. 
Figure 1.9 growth rates of both GDP and population.

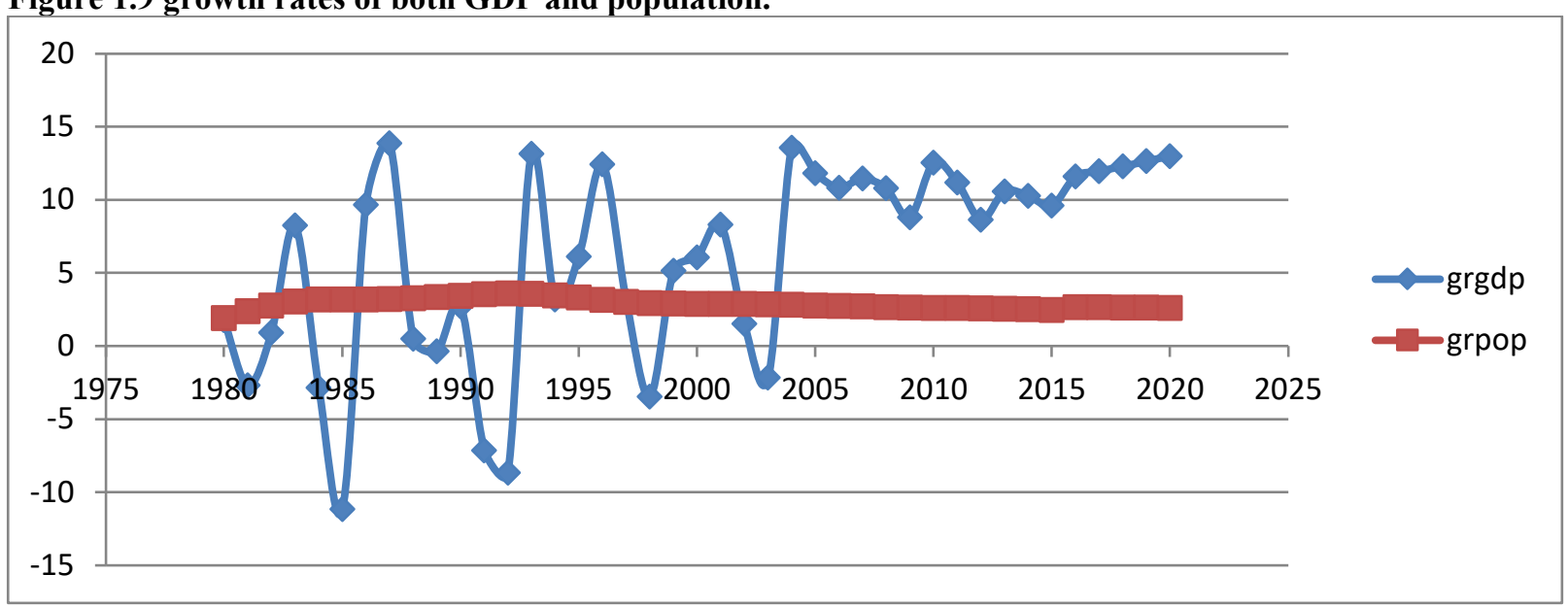

Source: own computation based on WB data.

\section{China:}

According to Brandon Lozeau (2007) he examines the effect of population growth on economic performance of china. The paper is based on the theoretical tools of Macroeconomic Theory and Statistics for Business courses. The basic finding of the paper is population and economic growth are related positively in the short run and negatively in the long run in case of china because population control policy of China has a key factor in slowing population growth however, other factors have contributed to the high level of Chinese economic performance in the face of an increasing population.

In the long run, Due to population control policies in China, the Chinese labour force will reach a peak and then begin to shrink causing a slowdown in Chinese economic growth. Barlow argues that the kind of economic growth seen in China is not sustainable because of this lagged fertility rate. The "one-child" policy implemented in China since 1978 has contributed to a low current fertility rate, while before the policy was implemented the fertility rate was 5.75, which has contributed to high lagged fertility. Barlow explains that low current fertility will eventually translate into low lagged fertility which, in turn, will mean a slowdown in economic expansion. So government must give attention for the technological progress that has allowed them to better sustain the population growth of the last few decades and increase their per capita income. Without this important technological progress a rise in the standard of living becomes very difficult and sustaining high population growth becomes more challenging.

\section{Population and GDP growth rate relationship:}

If we see the data from 1980-2015,

$>$ The average population growth rate is: -0.875519

$>$ The average GDP growth rate is: -9.695918

\section{* graphical illustrations and computation,}

Figure 1.10: growth rate of GDP

GROWTH RATE OF GDP AND POPULATION OF CHINA:

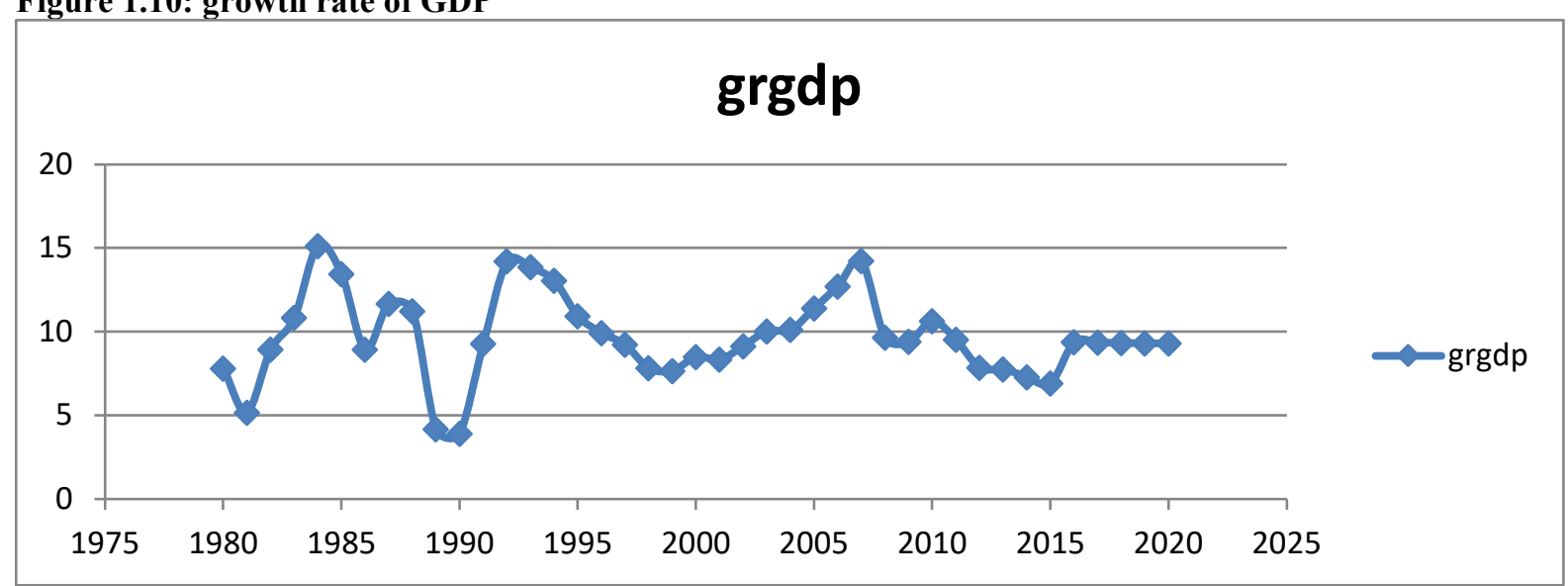

Source: own computation based on WB data. 
Figure 1.11 growth rate of population

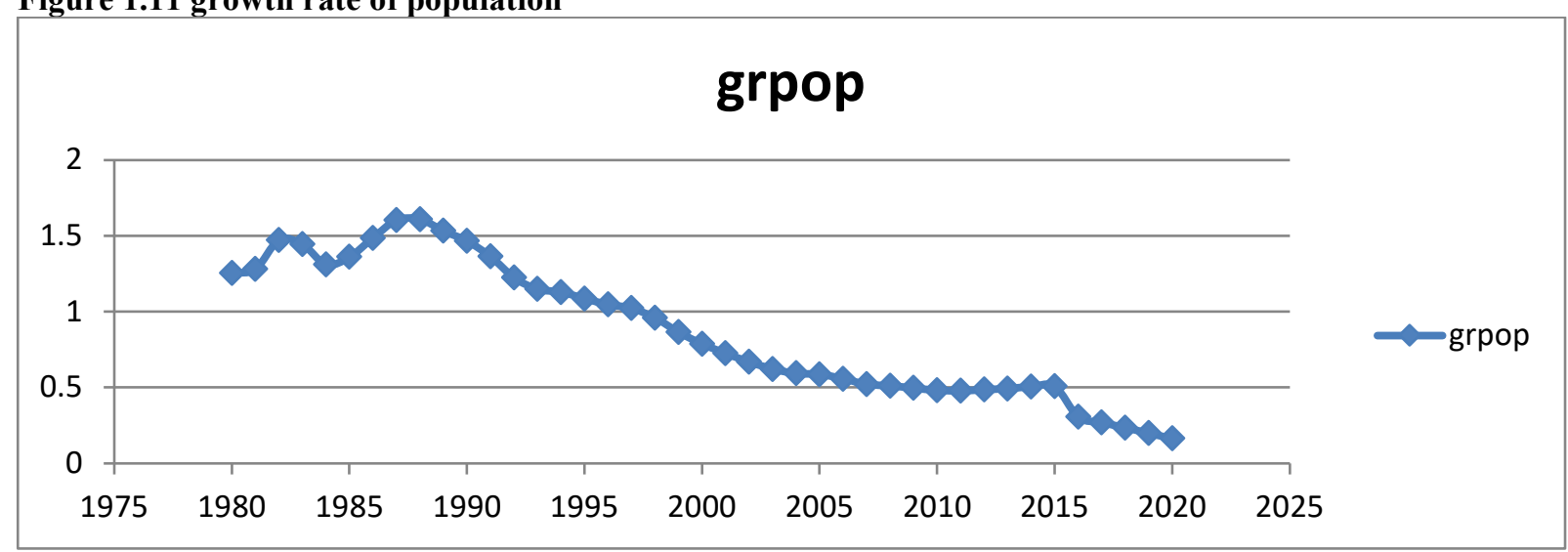

Source: own computation based on WB data.

Figure 1.12 growth rates of both GDP and population.

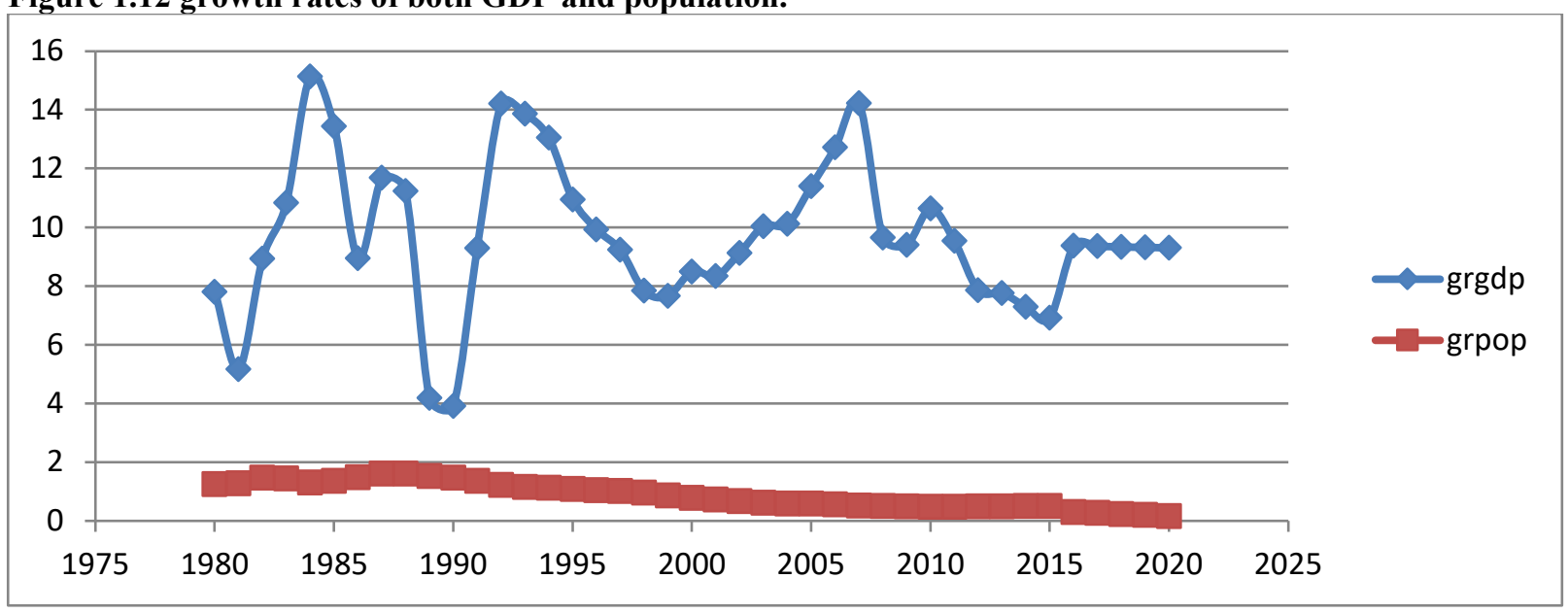

Source: own computation based on WB data.

\section{Conclusion}

As I mention above there are so many controversy on the issue of population and economic development relationship and also there are different views according to each country development history, some of them argues population growth affect negatively economic development others also say no it contribute positively by serving as labour force supplies and other important service.

When I come to my suggestion the impact of population growth on economic development is different in the varying economies. When in developed countries, population growth helped to increase the Gross National Product, in developing countries the reverse is the case. So that I support the view that population is not the real problem, since there is proper policy that can create opportunity for the growing population, the high population to become relevant.

However if the concerned body if fail to manipulate especially with regards to Less Developed Countries it become treat and challenge for the economic development of that country and the also high population cannot foster the economy when the largest portion is poor. Moreover it may bring different problem like continuously increasing dependency ratio, increase migration, unemployment, tends to lower man-land and man-resource proportions, can also increase the problems of inequalities in income distribution and generally it create poverty.

\section{REFERENCE}

Brandon Lozeau (2007), "the effect of population growth on economic performance of china".

FAO and the17 Sustainable Development Goals, 2015/16.

Kassahun Alemu (2014), "the Impact of Population Growth on the Ethiopian Economic Performance".

Klaus Grundler and Tommy Krieger (2015) using a new measure of democracy (SVMDI) based on the index of Support Vector Machines.

Martin (2011), "population and economic development". 
Sam Hak Kan TANG and Linda Chor Wing YUNG (2006), "the relationship between democracy and economic growth".

Sher Ali, Amjad Ali and Amjad Amin (2014), "the impact of Population growth on Economic Development of Pakistan" for period of 1975-2012.

Stephan Klasen and David Lawson (2009), "the Impact of Population Growth on Economic Growth and Poverty Reduction uses the interesting case study of Uganda" for time period 1960-2000.

UNDP, sustainable development goal 2015/16. 